\title{
An Integrated Model for Adjustment of Process Parameters to Recover Throughput Shortage in Semiconductor Assembly: A Case Study
}

\author{
Ho Kok Hoe ${ }^{1}(\mathbb{D})$, Joshua Prakash ${ }^{1}(\mathbb{D})$, Shahrul Kamaruddin² ${ }^{2}$, Ong Kok Seng ${ }^{1}$ (D) \\ ${ }^{1}$ Universiti Tunku Abdul Rabman (Malaysia) \\ ${ }^{2}$ Universiti Teknologi Petronas (Malaysia) \\ bokokhoe1980@gmail.com,joshuaj@utar.edu.my,shahrul.k@utp.edu.my,skong@utar.edu.my
}

Received: September 2018

Accepted: May 2019

\begin{abstract}
:
Purpose: Existing productivity improvements activities such as inventory buffer, overall equipment effectiveness (OEE) and total productive maintenance (TPM) do not associate the throughput shortage with the process parameters. The paper aims to develop and validate an integrated model to recover the throughput shortage through adjustment of process parameters in a semiconductor assembly setting.
\end{abstract}

Design/methodology/approach: The mathematical model of planned throughput as a function of process parameters in an integrated multiple-process line is developed. When the actual throughput does not meet the planned throughput, throughput shortage occurs. The planned throughput for the next day is summed with the throughput shortage from the previous day, and mathematical programming is used to search the adjusted values of the process parameters.

Findings: The throughput shortage can be restored at the following day with the reconfigured process parameters. If throughput shortage still exists, the additional throughput shortage will be carried forward to the subsequent day of planning where mathematical programming is repeated to search the adjusted values of the process parameters. The proposed optimisation model is essentially a parametric model, where actual data of process parameters are fitted into distribution and is translated into a range of allowable values within the $95 \%$ confidence interval.

Research limitations/implications: The process parameters subject to adjustment in this model are the cycle time of Die Attach, Wire Bond and Pre-Cap Inspection. Downtime and setup time are not subjected to adjustments because these parameters require more extensive efforts to be changed.

Practical implications: The mathematical programming computes adjusted values of process parameters to restore the throughput shortage, where it quantitatively correlates the process parameters and throughput shortage, rather than the conventional method of production improvement activities that do not quantitatively correlate with the throughput shortage.

Originality/value: The research addresses the adjustment of process parameters to recover the throughput shortage in integrated multiple-process line.

Keywords: adjustment of process parameters, throughput shortage, semiconductor assembly, productivity improvement, two-stage production planning 


\section{To cite this article:}

Hoe, H.K., Prakash, J., Kamaruddin, S., \& Seng, O.K. (2019). An integrated model for adjustment of process parameters to recover throughput shortage in semiconductor assembly: A case study. Journal of Industrial Engineering and Management, 12(2), 340-355. https://doi.org/10.3926/jiem.2742

\section{Introduction}

Nowadays, manufacturing industries are facing rising production cost, which creates an urgent need to manage throughput shortage in manufacturing systems. The effectiveness in managing throughput shortage is essential in reducing manufacturing cost (Tekin \& Sttk1, 2012). Throughput shortage manifests itself as the actual throughput is lower than the planned throughput (Gram, 2013). The potential causes of throughput shortage are unplanned machine breakdown, long setup, low production speed, high rework, and long start-up delay. Production control will always attempt to salvage the throughput shortage with the available resources.

There are various ways to recover throughput shortage. The first method is to create an inventory buffer. If the inventory buffer is not available to compensate for throughput deficiencies, the demand is lost or backordered at a relevant cost (Sana, 2012). The allocation of inventory buffer is needed to decouple processes with different production rates, caused by varying cycle times, machine breakdown, short stoppages and material shortage (Sana, 2012). This allocation is vital to sustain the operations of a manufacturing system. There are extensive studies related to the allocation of inventory buffer in production lines, such as by Enginarlar, Jingshan-Li and Zhang (2002), Miltenburg (2000) and Salameh and Ghattas (2001). In addition, Zequeira, Prida and Valdes (2004) developed a production-inventory model to search for optimal production periods between maintenance activities and the corresponding inventory buffer size to meet demand. Sana and Chaudhuri (2010) built a model for the production policy (resumption and non-resumption) to meet optimal safety stock, production rate and production lot size. Although the method ensures the production line continues running smoothly by maintaining sufficient work-in-process (WIP), there is the risk in inducing high holding cost and excessive WIP built-up due to excess buffer (Chan, Tasmin, Aziati, Rasi, Ismail \& Yaw, 2017; Nemtajela \& Mbohwa, 2017). If the buffer size is low, it may cause machine idling and underutilization which will delay processing, and unable to meet the due date. If the buffer size is sufficient, the machine is well decoupled, and the productivity is maximised.

Another method to recover throughput shortage is through improvement activities such as Overall Equipment Effectiveness (OEE), Total Productive Maintenance (TPM) and lean methodology. OEE and TPM are closely related to the gap between the actual and ideal performance of a manufacturing system. It focuses on three components which are availability, productivity, and quality. Most researches address the reduction of throughput shortage by improving efficiency in a manufacturing system. Tekin and Sttk1 (2012), Gram (2013) and Hassani and Hashemzadeh (2015) find and minimise the throughput shortage by adopting Overall Equipment Effectiveness (OEE) and Balance Score Card approach. The reduction of throughput shortage is examined through the identification of the root causes and specific measures to reduce the throughput shortage. Another method is the reduction of manufacturing wastes by adopting lean tools (Prajapati \& Deshpande, 2015; Siva, Patan, Kumar, Purusothaman, Pitchai \& Jegathish, 2017). Although the ideal cycle time represents the maximum theoretical speed of the equipment, the equipment may slow down and affect productivity despite high OEE (Anantharaman \& Nachiappan, 2006). The cycle time inefficiencies can be reduced through 5S, Jidoka, Muda, visual management and poka-yoke. Prajapati and Deshpande (2015) reviewed cycle time reduction using lean tools such as Kaizen and 'Takt' time analysis. Siva et al. (2017) utilised process improvement by cycle time reduction using lean tools such as visual management tool, poka-yoke, Kaizen and Jidoka.

The existing improvement in productivities and inventory buffer activities has no quantitative correlation between the improvement activities and throughput shortage. Such activities convert productivity gain on the output performance to recover the throughput shortage without linking effectively with the manufacturing parameters such as cycle time and machine downtime. In addition, the allowable cycle time of the equipment should be 
balanced with the product quality, as higher speed may cause more defects and affect the yield. It will also impact the equipment wear and tear, which will result in higher maintenance cost. Experience in inventory buffer management is particularly influenced by subjective judgement, as it is complex to establish a balanced buffer size between successive processes. In contrast, adjustment of process parameters is more objective and has a direct influence on the throughput.

In this paper, a model to recover the throughput shortage in a two-stage production planning system is proposed. The model links the throughput shortage with process parameters where these parameters can be adjusted within the feasible range. The rationale behind the adjustment of process parameters is to provide satisfactory throughput gain (Wuest, Weimer, Irgens \& Thoben, 2016). The cycle time of each process is adjusted to meet the planned throughput, which includes the throughput shortage. This is because the cycle time can be controlled while other process parameters such as downtime and setup time are stochastic, hence impractical to be adjusted (Sharma \& Jain, 2015; Xu, Zhao, Wu, Zhou, Ma \& Liu, 2016). Setup time on a machine is stochastic when there is variability in the length of setup time due to inconsistency in adjacent product types (Xu et al., 2016). In practice, the machine cycle time can be adjusted within an allowable range by adjusting the machine setting such as indexing time, delay in pick-up, delay in bonding, and bond time. The proposed model can create a relationship between throughput shortage and process parameters where these parameters are subject to changes in the manufacturing system. The parametric model uses input data of process parameters based on distributions that are translated into a range of allowable values within the $95 \%$ confidence interval. The extension of this benefit leads to effective production planning to recover the throughput shortage through better computation between improvement activities and manufacturing parameters. The proposed model is established to accommodate existing practise in production planning, throughput shortage recovery, and productivity improvement.

Section 1 reviews existing methods to recover the throughput shortage and their limitations. Section 2 presents the outline of the model used in this study. Section 3 describes the development of the proposed model. Section 4 validates the proposed model. Section 5 discusses the impact of the throughput shortage recovery using the proposed model. The conclusion drawn from the result is presented in Section 6.

\section{The Two-Stage Integrated Production Planning Model}

The proposed production planning model is used to plan daily throughput and recover throughput shortage concurrently in a real-time manufacturing scenario. The model is divided into two stages: daily throughput planning in the $1^{\text {st }}$ stage and throughput shortage recovery in the $2^{\text {nd }}$ stage. The $1^{\text {st }}$ stage estimates throughput using the mathematical model of planned throughput and is compared with the corresponding actual throughput. When there is throughput shortage (actual throughput less than planned throughput), the throughput shortage (difference in actual and planned throughput) is included in the subsequent day planning at the $2^{\text {nd }}$ stage. In the $2^{\text {nd }}$ stage, mathematical programming searches the optimum values of process parameters to meet the new projected throughput. However, if there is throughput shortage even after adjustment of process parameters, the throughput shortage will be included in subsequent day planning at the $2^{\text {nd }}$ stage for mathematical programming analysis until no further throughput shortage is encountered.

Figure 1 shows the flowchart of the approach adopted in the two-stage production planning model, expressed for a single period of seven days. The planned throughput is a function of process parameters and is based on data mining of the simulated data. The range of values of the process parameters is based on real-time data, fitted into distributions and translated into a range of allowable values within a $95 \%$ confidence interval. The data collection of relevant performance measures is based on full factorial runs of a simulation model, and the mathematical model of throughput as a function of process parameters is formulated using regression.

For day $i(i=1,2, \ldots . ., 7)$, the planned throughput, $\mathrm{O}_{\mathrm{M}}(\mathrm{i})$ is compared with actual throughput, $\mathrm{O}_{\mathrm{RT}}(\mathrm{i})$. If $\mathrm{O}_{\mathrm{RT}}(\mathrm{i})$ is less than $\mathrm{O}_{\mathrm{M}}(\mathrm{i})$, the next step is to proceed to the $2^{\text {nd }}$ stage since there is throughput shortage, $\mathrm{L}_{\mathrm{a}}(\mathrm{i})$.

On the next day $(\mathrm{i}+1)$, the mathematical programming adjusts the process parameters to estimate the attained throughput, $\mathrm{O}_{\mathrm{C}}(\mathrm{i}+1)$ that meet the projected throughput, $\mathrm{O}_{\mathrm{B}}(\mathrm{i}+1)$ which is the summation of planned throughput of day $i+1, \mathrm{O}_{\mathrm{M}}(\mathrm{i}+1)$ and the actual throughput shortage from day $\mathrm{i}, \mathrm{L}_{\mathrm{a}}(\mathrm{i})$. If $\mathrm{O}_{\mathrm{C}}(\mathrm{i}+1)$ is less than $\mathrm{O}_{\mathrm{B}}(i+1)$, there is 
still throughput shortage, $L_{p}(i+1)$. Thus, the next step is to repeat the mathematical programming procedure for next day $(i+2)$. The predicted throughput shortage, $L_{p}(i+1)$ is carried forward for the subsequent day (i+2) for the mathematical programming to estimate $\mathrm{O}_{\mathrm{C}}(\mathrm{i}+2)$ that can meet $\mathrm{O}_{\mathrm{B}}(\mathrm{i}+2)+\mathrm{L}_{\mathrm{p}}(\mathrm{i}+1)$ within the range of values of process parameters. This step is repeated as long as the predicted throughput shortage occurs. If there is no predicted throughput shortage, the $2^{\text {nd }}$ stage production planning is terminated, and the $1^{\text {st }}$ stage production planning is repeated for the subsequent day. The rationale of the methodology is to adjust values of process parameters only when there is throughput shortage or predicted throughput shortage.

The proposed production planning model is made up of the mathematical model of makespan, $\mathrm{T}_{\mathrm{B}}(\mathrm{i})$, the formulation of a mathematical model of planned throughput, $\mathrm{O}_{\mathrm{M}}(\mathrm{i})$, and mathematical programming of attained throughput, $\mathrm{O}_{\mathrm{C}}(\mathrm{i})$.

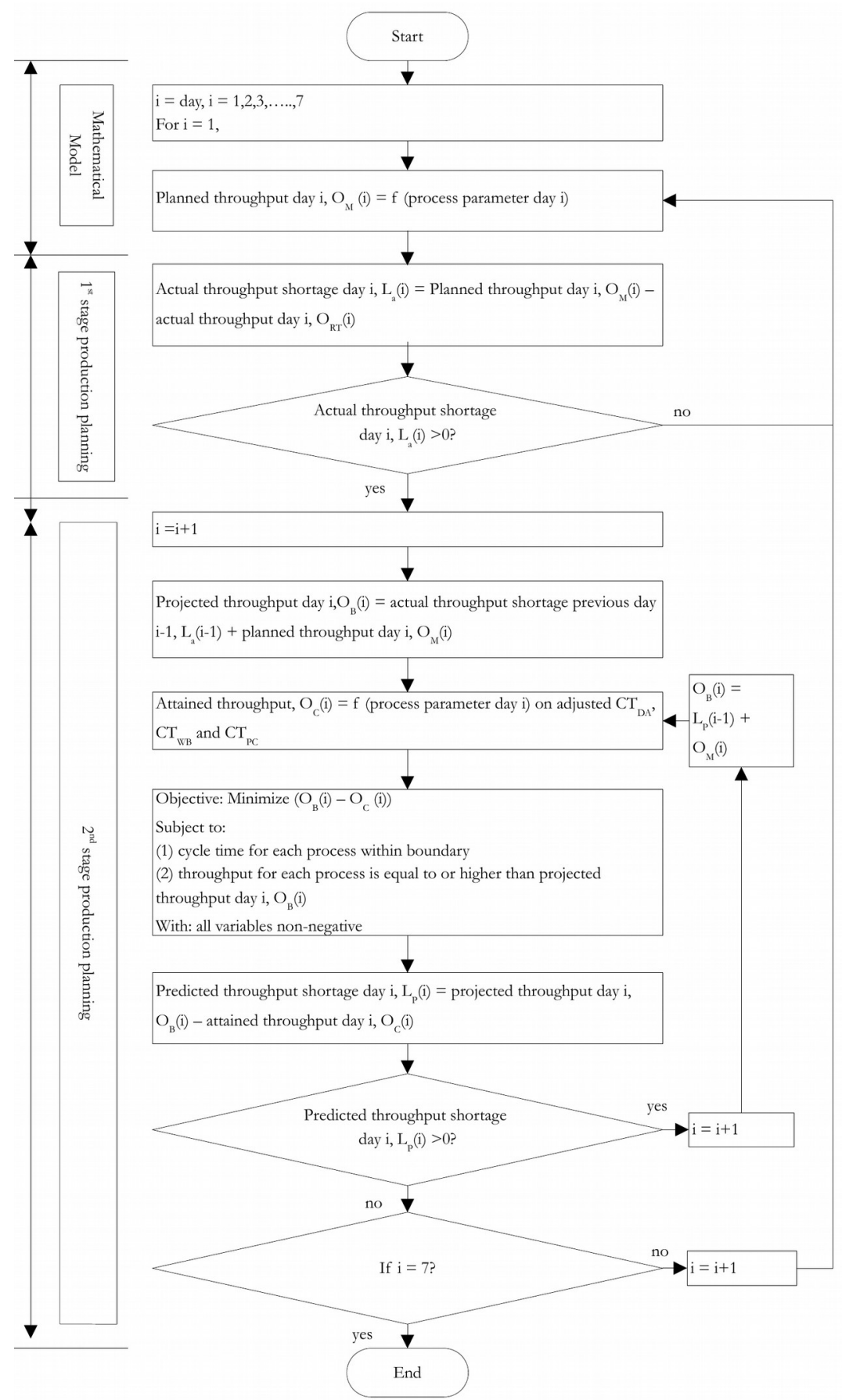

Figure 1. The two-stage production planning model for a single period 


\section{Model Development through a Case Study}

The case study was carried out in a semiconductor assembly line which consisted of three die attach machines, four oven cure machines, nine wire bond machines, and three pre-cap inspection machines. Figure 2 shows the process flow and the corresponding parameters in each process.

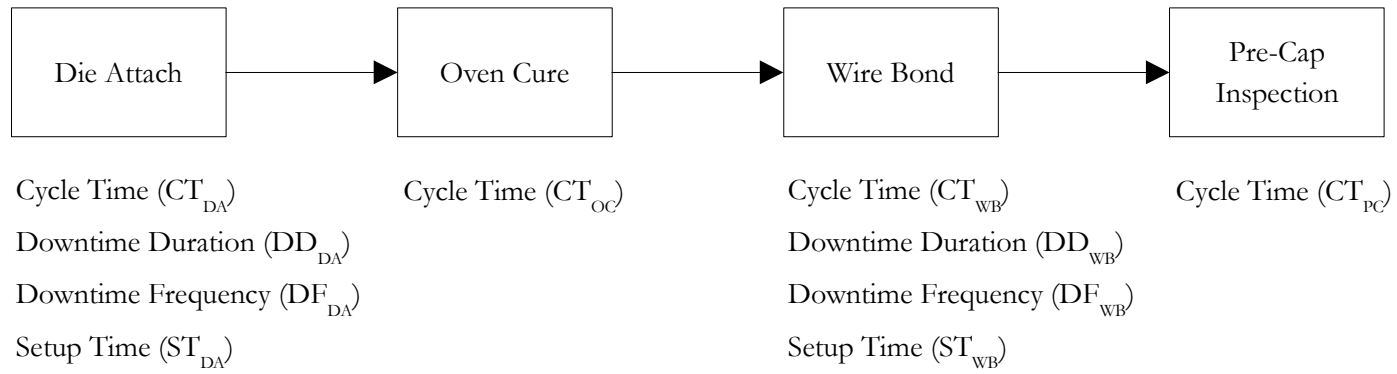

Figure 2. The process parameters for a semiconductor assembly line

Referring to Figure 2, the first process is Die Attach, where the machine processes the wafer into unit form. Each Die Attach machine processes one wafer at a time. The completed units are accumulated in batches before transferred to the next process, Oven Cure, where batches are placed in an oven for curing. Then, the batches are transferred to the next process, Wire Bond, where a wire was placed starting from the die to the lead frame of each unit. The Wire Bond machine processes one unit at one time. The completed units are accumulated in batches before it is sent to the next process, Pre-Cap Inspection, where the quality of each physical unit is inspected. The Pre-Cap Inspection machine inspects one unit at a time, and completed units are accumulated in batches before sent to the next process. In this study, the system ends when the batch completes the Pre-Cap Inspection. Setup is performed once during Die Attach and Wire Bond at the start of each day. An Oven Cure machine can accommodate up to eight batches at a time. No set up is required in Oven Cure and Pre-Cap Inspection.

The following stage is to identify the range of values of the process parameters. Table 1 shows the classification of process parameters and their values. The raw data is collected from the manufacturing system database throughout 30 days. The raw data are fitted into normal distribution (for cycle time) and exponential distribution (for downtime duration, downtime frequency and setup time) (Gandhi \& Harchol-Balter, 2009). 95\% confidence interval of the distribution determines the two levels of the process parameters which are the minimum and maximum. The two levels are further used in setting the range of allowable values during mathematical programming at the $2^{\text {nd }}$ stage.

\begin{tabular}{|c|c|c|c|c|}
\hline \multirow[b]{2}{*}{ Input Parameters } & \multirow[b]{2}{*}{ Unit } & \multicolumn{3}{|c|}{ Value } \\
\hline & & Low & Middle & High \\
\hline Cycle Time Die Attach $\left(\mathrm{CT}_{\mathrm{DA}}\right)$ & seconds & 2.8072 & - & 2.9460 \\
\hline Cycle Time Wire Bond (CT $\left.\mathrm{C}_{\mathrm{WB}}\right)$ & seconds & 6.0902 & - & 6.4609 \\
\hline Cycle Time Pre-Cap Inspection (CT $\left.\mathrm{T}_{\mathrm{PC}}\right)$ & seconds & 0.9882 & - & 1.0498 \\
\hline Downtime Duration Die Attach (DD & seconds & 2141 & - & 4391 \\
\hline Downtime Duration Wire Bond ( $\left.\mathrm{DD}_{\mathrm{WB}}\right)$ & seconds & 1364 & - & 2797 \\
\hline Downtime Frequency Die Attach $\left(\mathrm{DF}_{\mathrm{DA}}\right)$ & minutes & 1066 & - & 2187 \\
\hline Downtime Frequency Wire Bond $\left(\mathrm{DF}_{\mathrm{WB}}\right)$ & minutes & 1421 & - & 2193 \\
\hline Setup Time Die Attach $\left(\mathrm{ST}_{\mathrm{DA}}\right)$ & seconds & 2957 & - & 6063 \\
\hline Setup Time Wire Bond ( $\left.\mathrm{ST}_{\mathrm{WB}}\right)$ & seconds & 1324 & - & 2714 \\
\hline Batch size $(\mathrm{Q})$ & unit & 2200 & 3080 & 11264 \\
\hline Cycle Time Oven Cure (CT $\mathrm{OC})$ & seconds & & & 7200 \\
\hline
\end{tabular}

Table 1. Values of Process Parameters Classification 
The next step is to develop a mathematical model of makespan, $\mathrm{T}_{\mathrm{B}}$ and planned throughput, $\mathrm{O}_{\mathrm{M}}$ using regression. The planned throughput, $\mathrm{O}_{\mathrm{M}}$ is defined as the total time available in the system divided by the processing time of a unit in the system (Salvendry, 2007; Khan, 2007; Telsang, 2010). The planned throughput, $\mathrm{O}_{\mathrm{M}}$ can be written as shown in Equation (1).

$$
\mathrm{O}_{\mathrm{M}}=\frac{\mathrm{T}_{\mathrm{TOTAL}}}{\mathrm{T}_{\text {UNIT }}}
$$

Where:

$\mathrm{O}_{\mathrm{M}}=$ planned throughput per day

$\mathrm{T}_{\text {TOTAL }}=$ total time available per day

$\mathrm{T}_{\mathrm{UNIT}}=$ processing time per unit

The processing time per unit is the makespan, $\mathrm{T}_{\mathrm{B}}$ divided by the batch size $\mathrm{Q}$. The makespan, $\mathrm{T}_{\mathrm{B}}$ is the total length of processing time when all jobs of batch size $Q$ have finished processing. $T_{B}$ is obtained through data collection of 1536 experiment runs $\left(2^{9} \times 3^{1} \times 1^{1}=1536\right)$ collected from Pro-Model simulation model. The simulation model is built to represent the integrated processes of the semiconductor assembly line, and the process parameters from Table 1 are inserted into the model to obtain $\mathrm{T}_{\mathrm{b}}$ for each run. $\mathrm{O}_{\mathrm{M}}$ can now be calculated using Equation (2).

$$
\mathrm{O}_{\mathrm{M}}=\frac{\mathrm{T}_{\text {TOTAL }} \times \mathrm{Q}}{\mathrm{T}_{\mathrm{R}}}
$$

Where:

$\mathrm{O}_{\mathrm{M}}=$ planned throughput per day

$\mathrm{T}_{\mathrm{TOTAL}}=$ total time available per day

$\mathrm{Q}=$ batch size

$\mathrm{T}_{\mathrm{B}}=$ makespan

The full factorial runs of $\mathrm{T}_{\mathrm{B}}$ is inserted into statistical JMP software to formulate a regression model. $\mathrm{T}_{\mathrm{B}}$ as a function of process parameters is shown in Equation (3).

$$
\begin{gathered}
\mathrm{TB}=7187.5725+387.1239 \frac{\left[\mathrm{CT}_{\mathrm{DA}}-2.8766\right]}{0.0694}+1008.0011 \frac{\left[\mathrm{CT}_{\mathrm{WB}}-6.2756\right]}{0.1854}+157.9690 \frac{\left[\mathrm{CT}_{\mathrm{PC}}-1.019\right]}{0.0308}+ \\
9.5167 \frac{\left[\mathrm{DD}_{\mathrm{DA}}-3266\right]}{1125}+3.9325 \frac{\left[\mathrm{DD}_{\mathrm{WB}}-2080.5\right]}{716.5}+2.4477 \frac{\left[\mathrm{DF}_{\mathrm{DA}}-1626.5\right]}{560.5}-0.1807 \frac{\left[\mathrm{DF}_{\mathrm{WB}}-1807\right]}{386}- \\
2.6148 \frac{\left[\mathrm{ST}_{\mathrm{DA}}-4510\right]}{1553}+24.3713 \frac{\left[\mathrm{ST}_{\mathrm{WB}}-2019\right]}{695}+10.1729 \mathrm{Q}
\end{gathered}
$$

Where:

$\mathrm{T}_{\mathrm{B}}=$ makespan

$\mathrm{CT}_{\mathrm{DA}}=$ cycle time Die Attach

$\mathrm{CT}_{\mathrm{WB}}=$ cycle time Wire Bond

$\mathrm{CT}_{\mathrm{PC}}=$ cycle time Pre-Cap Inspection

$\mathrm{DD}_{\mathrm{DA}}=$ downtime duration Die Attach

$\mathrm{DD}_{\mathrm{WB}}=$ downtime duration Wire Bond

$\mathrm{DF}_{\mathrm{DA}}=$ downtime frequency Die Attach

$\mathrm{DF}_{\mathrm{WB}}=$ downtime frequency Wire Bond 
$\mathrm{ST}_{\mathrm{DA}}=$ setup time Die Attach

$\mathrm{ST}_{\mathrm{WB}}=$ setup time Wire Bond

$\mathrm{Q}=$ batch size

$\mathrm{T}_{\text {TOTAL }}$ is defined as the total time available per day in the system (Salvendry, 2007; Khan, 2007; Telsang, 2010). $\mathrm{T}_{\text {TOTAL }}$ is the summation of the individual process time available minus the setup time for each day. $\mathrm{M}$ is defined as the number of machines available at each process based on the process with the least capacity in the system. $T_{D}$ is defined as the maximum time per day. $A_{\mathrm{DA}}$ is defined as machine availability for Die Attach, and $A_{\mathbb{W B}}$ is defined as machine availability for a Wire Bond.

The total time available per day in the system, $\mathrm{T}_{\text {TOTAL }}$ is written as shown in Equation (4):

$$
\left.\mathrm{T}_{\mathrm{TOTAL}}=\left(\left(\mathrm{T}_{\mathrm{D}}-\mathrm{ST}_{\mathrm{DA}}\right)\left(\mathrm{A}_{\mathrm{DA}}\right)+\left(\mathrm{T}_{\mathrm{D}}\right)(1)+\left(\mathrm{T}_{\mathrm{D}}-\mathrm{ST}_{\mathrm{WB}}\right)\left(\mathrm{A}_{\mathrm{WB}}\right)\right)+\left(\mathrm{T}_{\mathrm{D}}\right)(1)\right) \times(\mathrm{M})
$$

Where:

$\mathrm{T}_{\mathrm{D}}=$ maximum time per day

$\mathrm{ST}_{\mathrm{DA}}=$ setup time Die Attach

$\mathrm{ST}_{\mathrm{WB}}=$ setup time Wire Bond

$\mathrm{A}_{\mathrm{DA}}=$ Die Attach availability

$A_{W B}=$ Wire Bond availability

$\mathrm{M}=$ number of machine available based on the process with least capacity in the system

The availability at Oven Cure and Pre-Cap Inspection is one because there is no downtime defined for these two processes. Besides, no setup is required during Oven Cure and Pre-Cap Inspection. Machine availability, A is defined in Equation (5) (Salvendry, 2007; Khan, 2007; Telsang, 2010).

$$
\mathrm{A}=\frac{\mathrm{MTBF}}{\mathrm{MTBF}+\mathrm{MTTR}}
$$

MTTR is defined in Equation (6):

$$
\text { MTTR }=\frac{\text { Machine Downtime Duration }}{\text { Machine Downtime Frequency }}=\frac{\mathrm{DD}_{\mathrm{P}}}{\left(\frac{\mathrm{DF}_{\mathrm{P}}}{1440}\right)}
$$

1440 minutes $=24$ hours $\times 60$ minutes; $\mathrm{p}=\mathrm{WB}$ (Wire Bond) or DA (Die Attach);

MTBF is defined in Equation (7):

$$
\text { MTBF }=\frac{86400-\text { Machine Downtime Duration }}{\text { Machine Downtime Frequency }}=\frac{86400-\mathrm{DD}_{\mathrm{P}}}{\left(\frac{\mathrm{DF}_{\mathrm{P}}}{1440}\right)}
$$

86400 seconds $=24$ hours $\times 60$ minutes $\times 60$ seconds; $\mathrm{p}=\mathrm{WB}$ (Wire Bond) or DA (Die Attach);

Equation (6) and Equation (7) are substituted in Equation (5) and is written as shown in Equation (8).

$$
\mathrm{A}=\frac{86400-\mathrm{DD}_{\mathrm{P}}}{86400}
$$

Equation (3), Equation (4) and Equation (8) are incorporated into Equation (2) where the planned throughput, $\mathrm{O}_{\mathrm{M}}$ as a function of input parameters is written as shown in Equation (9): 


$$
\begin{gathered}
\mathrm{O}_{\mathrm{M}}=\frac{\left(\left(\mathrm{T}_{\mathrm{D}}-\mathrm{ST}_{\mathrm{DA}}\right)\left(\frac{86400-\mathrm{DD}_{\mathrm{DA}}}{86400}\right)+\left(\mathrm{T}_{\mathrm{D}}\right)(1)+\left(\mathrm{T}_{\mathrm{D}}-\mathrm{ST}_{\mathrm{WB}}\right)\left(\frac{86400-\mathrm{DD}_{\mathrm{WB}}}{86400}\right)+\left(\mathrm{T}_{\mathrm{D}}\right)(1)\right)}{\mathrm{x}(\mathrm{M}) \times \mathrm{Q}} \\
+9.5167 \frac{\left[\mathrm{DD}_{\mathrm{DA}}-3266\right]}{1125}+3.9325 \frac{\left[\mathrm{DD}_{\mathrm{WB}}-2080.5\right]}{716.5}+2.4477 \frac{\left[\mathrm{DF}_{\mathrm{DA}}-31626.5\right]}{560.5}-0.1807 \frac{\left[\mathrm{CT}_{\mathrm{WA}}-2.8766\right]}{0.0694}+10+080011 \frac{\left[\mathrm{CT}_{\mathrm{WB}}-6.2756\right]}{0.1854}+157.9690 \frac{\left[\mathrm{CT}_{\mathrm{PC}}-1.019\right]}{0.0308} \\
2.6148 \frac{\left[\mathrm{ST}_{\mathrm{DA}}-4510\right]}{1553}+24.3713 \frac{\left[\mathrm{ST}_{\mathrm{WB}}-2019\right]}{695}+10.1729 \mathrm{Q}
\end{gathered}
$$

\section{Step 1: $1^{\text {st }}$ Stage of Production Planning}

The validity of the model is tested in three different periods. A single period of the model is defined as seven days $(\mathrm{n}=7)$ where day $\mathrm{i}(\mathrm{i}=1,2,3, \ldots . ., 7)$. For day $1(\mathrm{i}=1), \mathrm{O}_{\mathrm{M}}(1)$ is estimated based on Equation (9) as a function of process parameters of day 1 . The planned throughput, $\mathrm{O}_{\mathrm{M}}(1)$ is compared with actual throughput, $\mathrm{O}_{\mathrm{RT}}(1)$, to assess if there is actual throughput shortage, $\mathrm{L}_{\mathrm{a}}(1)$. If $\mathrm{O}_{\mathrm{RT}}(1)>\mathrm{O}_{\mathrm{M}}(1)$, there is no actual throughput shortage and the planned throughput, for day 2, $\mathrm{O}_{\mathrm{M}}(2)$ is estimated using Equation (9). If there is actual throughput shortage in day 1 , where $\mathrm{O}_{\mathrm{RT}}(1)<\mathrm{O}_{\mathrm{M}}(1), \mathrm{L}_{\mathrm{a}}(1)$ will be carried forward to the $2^{\text {nd }}$ stage of production planning for day 2 . Generally, if the actual throughput shortage for day $i, \mathrm{~L}_{\mathrm{a}}(\mathrm{i})$ is zero or negative, the planned throughput for day $(\mathrm{i}+1), \mathrm{O}_{\mathrm{M}}(\mathrm{i}+1)$ is estimated using Equation (9). On the other hand, if the actual throughput shortage of day $i, L_{a}(i)$ is positive, the throughput shortage will be carried forward to the $2^{\text {nd }}$ stage of production planning for day $i+1$.

\section{Step 2: $2^{\text {nd }}$ Stage of Production Planning}

$2^{\text {nd }}$ stage of production planning is involved when there is throughput shortage incurred at the $1^{\text {st }}$ stage of production planning. In the $2^{\text {nd }}$ stage of production planning, the projected throughput of the day $i+1, \mathrm{O}_{\mathrm{B}}(\mathrm{i}+1)$ is the sum of actual throughput shortage from previous day $i, \mathrm{~L}_{\mathrm{a}}(\mathrm{i})$ and planned throughput of the day $\mathrm{i}+1, \mathrm{O}_{\mathrm{M}}(\mathrm{i}+1)$. The cycle time of the processes $\left(\mathrm{CT}_{\mathrm{DA}}, \mathrm{CT}_{\mathrm{WB}}\right.$ and $\left.\mathrm{CT}_{\mathrm{PC}}\right)$ need to be adjusted to ensure $\mathrm{O}_{\mathrm{B}}(\mathrm{i})$ is met. The attained throughput for day $\mathrm{i}+1, \mathrm{O}_{\mathrm{C}}(\mathrm{i}+1)$ is a function of the adjusted cycle time values $\left(\mathrm{CT}_{\mathrm{DA}}, \mathrm{CT}_{\mathrm{WB}}\right.$ and $\left.\mathrm{CT}_{\mathrm{PC}}\right)$ obtained by mathematical programming. This is because the cycle time can be controlled while the downtime and setup time are stochastic, hence impractical to be manipulated. The cycle time can be controlled by the machine settings, such as by changing the delay time or by adjusting the movement mechanism of the machine parts. $\mathrm{O}_{\mathrm{B}}(\mathrm{i}+1)$ is obtained using Equation (10).

$$
\text { If } \mathrm{O}_{\mathrm{M}}(\mathrm{i})-\mathrm{O}_{\mathrm{RT}}(\mathrm{i})>0 \text {, then } \mathrm{O}_{\mathrm{B}}(\mathrm{i}+1)=\mathrm{O}_{\mathrm{M}}(\mathrm{i}+1)+\mathrm{O}_{\mathrm{M}}(\mathrm{i})-\mathrm{O}_{\mathrm{RT}}(\mathrm{i})
$$

In the mathematical programming development, the objective function is to minimize the difference between attained throughput of day $\mathrm{i}+1, \mathrm{O}_{\mathrm{C}}(\mathrm{i}+1)$ and projected throughput of day $\mathrm{i}+1, \mathrm{O}_{\mathrm{B}}(\mathrm{i}+1)$.

The mathematical programming model in the $2^{\text {nd }}$ stage of the model is formulated as follows in Equation (11) to Equation (20):

Objective function:

$$
\text { Minimize } \mathrm{OM}(\mathrm{i}+1)+(\mathrm{OM}(\mathrm{i})-\mathrm{ORT}(\mathrm{i}))-\frac{\mathrm{T}_{\mathrm{TOTAL}} \mathrm{x} \mathrm{Q}}{\mathrm{T}_{\mathrm{B}}}
$$

Constraints:

$$
\begin{aligned}
& \mathrm{CT}_{\mathrm{DA}}(\mathrm{i}+1) \geq 2.8072 \\
& \mathrm{CT}_{\mathrm{DA}}(\mathrm{i}+1) \leq 2.9460 \\
& \mathrm{CT}_{\mathrm{WB}}(\mathrm{i}+1) \geq 6.0902
\end{aligned}
$$




$$
\begin{gathered}
\mathrm{CT}_{\mathrm{WB}}(\mathrm{i}+1) \leq 6.4609 \\
\mathrm{CT}_{\mathrm{PC}}(\mathrm{i}+1) \geq 0.9882 \\
\mathrm{CT}_{\mathrm{PC}}(\mathrm{i}+1) \leq 1.0498 \\
{\left[\frac{\left[\left(86400-\mathrm{ST}_{\mathrm{DA}}(\mathrm{i}+1)\right) \times\left(86400 \times\left(86400-\mathrm{DD}_{\mathrm{DA}}(\mathrm{i}+1)\right)\right)\right]}{\mathrm{CT} \mathrm{T}_{\mathrm{DA}}(\mathrm{i}+1)}\right] \times 3 \geq \mathrm{O}_{\mathrm{B}}(\mathrm{i}+1)} \\
{\left[\frac{\left[\left(86400-\mathrm{ST}_{\mathrm{WB}}(\mathrm{i}+1)\right) \times\left(86400 \times\left(86400-\mathrm{DD}_{\mathrm{WB}}(\mathrm{i}+1)\right)\right)\right]}{\mathrm{C} \mathrm{T}_{\mathrm{WB}}(\mathrm{i}+1)}\right] \times 9 \geq \mathrm{O}_{\mathrm{B}}(\mathrm{i}+1)} \\
{\left[\frac{(86400 \times 1)}{\mathrm{C} \mathrm{T}_{\mathrm{PC}}(\mathrm{i}+1)}\right] \times 3 \geq \mathrm{O}_{\mathrm{B}}(\mathrm{i}+1)}
\end{gathered}
$$

Equation (11) states that the objective function is to minimise the difference between the attained throughput of day $i+1, \mathrm{O}_{\mathrm{C}}(i+1)$ and the projected throughput of day $\mathrm{i}+1, \mathrm{O}_{\mathrm{B}}(\mathrm{i}+1)$. Equation (12) to Equation (17) ensures that the cycle times fall within the boundary of the allowable values defined in Table 1. Equation (18) to Equation (20) ensures that the throughput for each process is at least equal or higher than $\mathrm{O}_{\mathrm{B}}(\mathrm{i}+1)$. Equation (18) to Equation (20) is important to validate whether $\mathrm{O}_{\mathrm{C}}(\mathrm{i}+1)$ can meet $\mathrm{O}_{\mathrm{B}}(\mathrm{i}+1)$.

If there is no additional predicted throughput shortage, the planned throughput for subsequent day $\mathrm{i}+2, \mathrm{O}_{\mathrm{M}}(\mathrm{i}+2)$ is estimated using $1^{\text {st }}$ stage of production planning. If $\left(\mathrm{O}_{\mathrm{B}}(\mathrm{i}+1)-\mathrm{O}_{\mathrm{C}}(\mathrm{i}+1)\right)$ for day $\mathrm{i}+1$ is positive, there is additional predicted throughput shortage at the $2^{\text {nd }}$ stage of production planning. The predicted throughput shortage is carried forward to the subsequent day, and the $2^{\text {nd }}$ stage of production planning is repeated for day $i+2$ where $\mathrm{O}_{\mathrm{C}}(\mathrm{i}+2)$ is estimated to meet $\mathrm{O}_{\mathrm{B}}(\mathrm{i}+2)$ using mathematical programming. The model is valid for multiple-period as long as the process parameters in each period fall within the range of values shown in Table 1 . Three different periods of real-time data are collected to validate the model in a real-time scenario. Each period consists of seven days.

\section{Validation of the Proposed Production Planning Model \\ Case Study 1: Period 1}

Table 2 shows the production planning data obtained for the $1^{\text {st }}$ period of 7 days. For day 1 in the $1^{\text {st }}$ stage of production planning, $\mathrm{O}_{\mathrm{M}}(1)$ is estimated at 81412 units. $\mathrm{O}_{\mathrm{RT}}(1)$ is 77982 units. Since $\mathrm{O}_{\mathrm{M}}(1)$ is higher than $\mathrm{O}_{\mathrm{RT}}(1)$, there is throughput shortage; thus the throughput shortage of day $1,\left(\mathrm{~L}_{a}(1)=3430\right.$ units $)$ is carried forward to the $2^{\text {nd }}$ stage of production planning. For day 2, $\mathrm{O}_{\mathrm{M}}(2)$ is estimated at 72110 units. The throughput shortage from day 1, $\mathrm{L}_{\mathrm{a}}(1)$ is added to the planned throughput of day $2, \mathrm{O}_{\mathrm{M}}(2) \cdot \mathrm{O}_{\mathrm{B}}(2)$ is calculated as $\mathrm{O}_{\mathrm{M}}(2)+\mathrm{L}_{\mathrm{a}}(1)$ where it is equal to 75539 units. In the $2^{\text {nd }}$ stage, the mathematical programming assessed the adjusted cycle time within the boundary shown in Table 1 and estimated $\mathrm{O}_{C}(2)$ as 75539 units. Since $\mathrm{O}_{C}(2)$ is equal to $\mathrm{O}_{B}(2)$, there is no predicted throughput shortage that is required to be carried forward to the next day ( $\mathrm{i}=3$ ).

For day 3 in the $1^{\text {st }}$ stage of production planning, $\mathrm{O}_{\mathrm{M}}(3)$ is estimated at 90693 units. $\mathrm{O}_{\mathrm{RT}}(1)$ is 86452 units. Since $\mathrm{O}_{\mathrm{M}}(3)$ is higher than $\mathrm{O}_{\mathrm{RT}}(3)$, there is throughput shortage; thus the throughput shortage of day $3,\left(\mathrm{~L}_{\mathrm{a}}(3)=4241\right.$ units) is carried forward to the $2^{\text {nd }}$ stage of production planning. For day $4, \mathrm{O}_{\mathrm{M}}(4)$ is estimated at 70974 units. The throughput shortage from day $3, \mathrm{~L}_{\mathrm{a}}(3)$ is added to the planned throughput of day $4, \mathrm{O}_{\mathrm{M}}(4) . \mathrm{O}_{\mathrm{B}}(4)$ is calculated as $\mathrm{O}_{\mathrm{M}}(4)+\mathrm{L}_{\mathrm{a}}(3)$ where it is equal to 75215 units. In the $2^{\text {nd }}$ stage, the mathematical programming assessed the adjusted cycle time within the boundary shown in Table 1 and estimated $O_{C}(4)$ as 75215 units. Since $O_{C}(4)$ is equal to $\mathrm{O}_{\mathrm{B}}(4)$, there is no predicted throughput shortage that is required to be carried forward to the next day $(\mathrm{i}=5)$.

$\mathrm{O}_{\mathrm{M}}(5)$ is estimated at 72538 units, and $\mathrm{O}_{\mathrm{RT}}(5)$ is 59321 units. Since $\mathrm{O}_{\mathrm{M}}(5)$ is higher than $\mathrm{O}_{\mathrm{RT}}(5)$, there is throughput shortage; thus the throughput shortage of day $5,\left(\mathrm{~L}_{a}(5)=13217\right.$ units) is carried forward to the $2^{\text {nd }}$ stage of production planning. For day $6, \mathrm{O}_{\mathrm{M}}(6)$ is estimated at 78620 units. The throughput shortage from day $5, \mathrm{~L}_{\mathrm{a}}(5)$ is added to the planned throughput of day $6, \mathrm{O}_{\mathrm{M}}(6) . \mathrm{O}_{\mathrm{B}}(6)$ is calculated as $\mathrm{O}_{\mathrm{M}}(6)+\mathrm{L}_{\mathrm{a}}(5)$ where it is equal to 91837 units. In the $2^{\text {nd }}$ stage, the mathematical programming assessed the adjusted cycle time within the boundary shown 
in Table 1 and estimated $\mathrm{O}_{C}(6)$ as 91837 units. Since $\mathrm{O}_{C}(6)$ is equal to $\mathrm{O}_{\mathrm{B}}(6)$, there is no predicted throughput shortage that is required to be carried forward to the next day $(\mathrm{i}=7)$.

For day $7, \mathrm{O}_{\mathrm{M}}(7)$ is estimated at 92051 units, and $\mathrm{O}_{\mathrm{RT}}(7)$ is 73100 . Since $\mathrm{O}_{\mathrm{M}}(7)$ is higher than $\mathrm{O}_{\mathrm{RT}}(7)$, there is throughput shortage; thus the throughput shortage of day $7,\left(\mathrm{~L}_{a}(7)=18951\right.$ units $)$ is carried forward to the $2^{\text {nd }}$ stage of production planning for day 8 . Since the case study is limited to seven days period, the analysis stops at this point.

\begin{tabular}{|c|c|c|c|c|c|c|c|c|}
\hline & \multirow{2}{*}{$\begin{array}{l}\text { Process } \\
\text { Variables }\end{array}$} & \multicolumn{7}{|c|}{ Day } \\
\hline & & 1 & 2 & 3 & 4 & 5 & 6 & 7 \\
\hline \multirow{16}{*}{$1^{\text {st }}$ stage } & $\mathrm{CT}_{\mathrm{DA}}$ & 2.8346 & 2.907 & 2.9342 & 2.8936 & 2.9046 & 2.8971 & 2.8378 \\
\hline & $\mathrm{CT}_{\mathrm{OC}}$ & 7200 & 7200 & 7200 & 7200 & 7200 & 7200 & 7200 \\
\hline & $\mathrm{CT}_{\mathbb{W B}}$ & 6.1796 & 6.3721 & 6.1890 & 6.3850 & 6.2920 & 6.2297 & 6.2860 \\
\hline & $\mathrm{CT}_{\mathrm{PC}}$ & 0.9973 & 1.0256 & 1.0200 & 1.0450 & 1.0123 & 1.0150 & 1.0190 \\
\hline & $\mathrm{DD}_{\mathrm{DA}}$ & 2241 & 3190 & 2845 & 3986 & 4097 & 3967 & 2988 \\
\hline & $\mathrm{DD}_{\mathrm{WB}}$ & 1599 & 1987 & 2366 & 1822 & 1769 & 2544 & 1479 \\
\hline & $\mathrm{DF}_{\mathrm{DA}}$ & 1601 & 2067 & 1339 & 1845 & 1937 & 2080 & 2065 \\
\hline & $\mathrm{DF}_{\mathrm{WB}}$ & 1790 & 1544 & 1988 & 1756 & 2147 & 2079 & 1655 \\
\hline & $\mathrm{ST}_{\mathrm{DA}}$ & 3867 & 3099 & 5427 & 4635 & 4906 & 3782 & 3056 \\
\hline & $\mathrm{ST}_{\mathrm{WB}}$ & 1436 & 1788 & 1867 & 2090 & 1645 & 2654 & 2017 \\
\hline & $\mathrm{M}$ & 3 & 3 & 3 & 3 & 3 & 3 & 3 \\
\hline & $\mathrm{T}_{\text {TOTAL }}$ & 994433 & 992858 & 979236 & 980697 & 981625 & 980148 & 993847 \\
\hline & Q & 3080 & 2200 & 11264 & 2200 & 2200 & 3080 & 11264 \\
\hline & $\mathrm{O}_{\mathrm{M}}$ & 81412 & 72110 & 90693 & 70974 & 72538 & 78620 & 92051 \\
\hline & $\mathrm{O}_{\mathrm{RT}}$ & 77982 & 59124 & 86452 & 58429 & 59321 & 72128 & 73100 \\
\hline & $\mathrm{L}_{\mathrm{a}}$ & 3430 & 12986 & 4241 & 12545 & 13217 & 6492 & 18951 \\
\hline \multirow{6}{*}{$\begin{array}{l}2^{\text {nd }} \\
\text { stage }\end{array}$} & $\mathrm{O}_{\mathrm{B}}$ & - & 75539 & - & 75215 & - & 91837 & - \\
\hline & $\mathrm{O}_{\mathrm{C}}$ & - & 75539 & - & 75215 & - & 91837 & - \\
\hline & $\mathrm{L}_{\mathrm{p}}$ & - & 0 & - & 0 & - & 0 & - \\
\hline & Adjusted $\mathrm{CT}_{\mathrm{DA}}$ & - & 2.8072 & - & 2.8693 & - & 2.0670 & - \\
\hline & Adjusted $\mathrm{CT}_{\mathrm{WB}}$ & - & 6.2568 & - & 6.0902 & - & 6.0902 & - \\
\hline & Adjusted $\mathrm{CT}_{\mathrm{PC}}$ & - & 0.9882 & - & 1.0498 & - & 0.9882 & - \\
\hline
\end{tabular}

Table 2. $1^{\text {st }}$ Stage and $2^{\text {nd }}$ Stage of Production Planning for $1^{\text {st }}$ Period

\section{Case Study 2: Period 2}

Table 3 shows the production planning data obtained for the $2^{\text {nd }}$ period for 7 days. For day 1 in the $1^{\text {st }}$ stage of production planning, $\mathrm{O}_{\mathrm{M}}(1)$ is estimated at 90772 units. $\mathrm{O}_{\mathrm{RT}}(1)$ is 85756 units. Since $\mathrm{O}_{\mathrm{M}}(1)$ is higher than $\mathrm{O}_{\mathrm{RT}}(1)$, there is throughput shortage; thus the throughput shortage of day 1, $\left(\mathrm{L}_{a}(1)=5016\right.$ units) is carried forward to the $2^{\text {nd }}$ stage of production planning. For day $2, \mathrm{O}_{\mathrm{M}}(2)$ is estimated at 78789 units. The throughput shortage from day $1, \mathrm{~L}_{\mathrm{a}}(1)$ is added to the planned throughput of day $2, \mathrm{O}_{\mathrm{M}}(2) . \mathrm{O}_{\mathrm{B}}(2)$ is calculated as $\mathrm{O}_{\mathrm{M}}(2)+$ $\mathrm{L}_{\mathrm{a}}(1)$ where it is equal to 83805 units. In the $2^{\text {nd }}$ stage, the mathematical programming assessed the adjusted cycle time within the boundary shown in Table 1 and estimated $\mathrm{O}_{\mathrm{C}}(2)$ as 81257 units. Since $\mathrm{O}_{\mathrm{C}}(2)$ is lower than $\mathrm{O}_{\mathrm{B}}(2)$, there is a predicted throughput shortage that is required to be carried forward to the next day ( $\mathrm{i}=3$ ). $\mathrm{L}_{\mathrm{p}}(2)$ is 2548 units. 
$\mathrm{O}_{\mathrm{M}}(3)$ is estimated at 80136 units. The predicted throughput shortage from day $2, \mathrm{~L}_{\mathrm{p}}(2)$ is added to the planned throughput of day $3, \mathrm{O}_{\mathrm{M}}(3) . \mathrm{O}_{\mathrm{B}}(3)$ is calculated as $\mathrm{O}_{\mathrm{M}}(4)+\mathrm{L}_{\mathrm{p}}(3)$ where it is equal to 82684 units. In the $2^{\text {nd }}$ stage, the mathematical programming assessed the adjusted cycle time within the boundary shown in Table 1 and estimated $\mathrm{O}_{\mathrm{C}}(3)$ as 81980 units. Since $\mathrm{O}_{\mathrm{C}}(3)$ is lower than $\mathrm{O}_{\mathrm{B}}(3)$, there is a predicted throughput shortage that is required to be carried forward to the next day $(\mathrm{i}=4)$. $\mathrm{L}_{\mathrm{p}}(3)$ is 704 units.

\begin{tabular}{|c|c|c|c|c|c|c|c|c|}
\hline & \multirow{2}{*}{$\begin{array}{l}\text { Process } \\
\text { Variables }\end{array}$} & \multicolumn{7}{|c|}{ Day } \\
\hline & & 1 & 2 & 3 & 4 & 5 & 6 & 7 \\
\hline \multirow{16}{*}{$1^{\text {st }}$ stage } & $\mathrm{CT}_{\mathrm{DA}}$ & 2.8432 & 2.8342 & 2.9032 & 2.9178 & 2.8190 & 2.8772 & 2.8100 \\
\hline & $\mathrm{CT}_{\mathrm{OC}}$ & 7200 & 7200 & 7200 & 7200 & 7200 & 7200 & 7200 \\
\hline & $\mathrm{CT}_{\mathrm{WB}}$ & 6.1901 & 6.2720 & 6.1126 & 6.3301 & 6.1450 & 6.3021 & 6.2378 \\
\hline & $\mathrm{CT}_{\mathrm{PC}}$ & 1.0079 & 0.9220 & 1.0260 & 1.0348 & 0.9972 & 1.0152 & 1.020 \\
\hline & $\mathrm{DD}_{\mathrm{DA}}$ & 3990 & 4010 & 3720 & 2899 & 2690 & 2477 & 3320 \\
\hline & $\mathrm{DD}_{\mathrm{WB}}$ & 2265 & 2740 & 1608 & 1790 & 2011 & 2390 & 2700 \\
\hline & $\mathrm{DF}_{\mathrm{DA}}$ & 1205 & 1580 & 1945 & 1540 & 1766 & 2010 & 2087 \\
\hline & $\mathrm{DF}_{\mathrm{WB}}$ & 1742 & 1823 & 2009 & 1990 & 2080 & 1590 & 1630 \\
\hline & $\mathrm{ST}_{\mathrm{DA}}$ & 4932 & 5109 & 3550 & 5742 & 5230 & 4480 & 5020 \\
\hline & $\mathrm{ST}_{\mathrm{WB}}$ & 2430 & 2054 & 2689 & 2090 & 2190 & 1988 & 1420 \\
\hline & M & 3 & 3 & 3 & 3 & 3 & 3 & 3 \\
\hline & $\mathrm{T}_{\text {TOTAL }}$ & 975787 & 975532 & 984679 & 977745 & 979935 & 984775 & 981757 \\
\hline & Q & 11264 & 3080 & 3080 & 11264 & 2200 & 2200 & 3080 \\
\hline & $\mathrm{O}_{\mathrm{M}}$ & 90772 & 78789 & 80136 & 89995 & 75844 & 72967 & 79716 \\
\hline & $\mathrm{O}_{\mathrm{RT}}$ & 85756 & 73278 & 67341 & 68945 & 72677 & 60832 & 75200 \\
\hline & $\mathrm{L}_{\mathrm{a}}$ & 5016 & 5511 & 12795 & 21050 & 3167 & 12135 & 4516 \\
\hline \multirow{6}{*}{$2^{\text {nd }}$ stage } & $\mathrm{O}_{\mathrm{B}}$ & - & 83805 & 82684 & 90699 & - & 76134 & - \\
\hline & $\mathrm{O}_{\mathrm{C}}$ & - & 81257 & 81980 & 90789 & - & 76134 & - \\
\hline & $\mathrm{L}_{\mathrm{p}}$ & - & 2548 & 704 & -90 & - & 0 & - \\
\hline & Adjusted $\mathrm{CT}_{\mathrm{DA}}$ & - & 2.8072 & 2.8072 & 2.9460 & - & 2.8072 & - \\
\hline & Adjusted $\mathrm{CT}_{\mathrm{WB}}$ & - & 6.0902 & 6.0902 & 6.0902 & - & 6.1722 & - \\
\hline & Adjusted $\mathrm{CT}_{\mathrm{PC}}$ & - & 0.9882 & 0.9882 & 1.0498 & - & 0.9882 & - \\
\hline
\end{tabular}

Table 3. $1^{\text {st }}$ Stage and $2^{\text {nd }}$ Stage of Production Planning for $2^{\text {nd }}$ Period

$\mathrm{O}_{\mathrm{M}}(4)$ is estimated at 89995 units. The predicted throughput shortage from day $3, \mathrm{~L}_{\mathrm{p}}(3)$ are added to the planned throughput of day $4, \mathrm{O}_{\mathrm{M}}(4) . \mathrm{O}_{\mathrm{B}}(4)$ is calculated as $\mathrm{O}_{\mathrm{M}}(4)+\mathrm{L}_{\mathrm{p}}(3)$ where it is equal to 90699 units. In the $2^{\text {nd }}$ stage, the mathematical programming assessed the adjusted cycle time within the boundary shown in Table 1 and estimated $\mathrm{O}_{C}(4)$ as 90789 units. Since $\mathrm{O}_{C}(4)$ is higher than $\mathrm{O}_{\mathrm{B}}(4)$, there is no predicted throughput shortage that is required to be carried forward to the next day $(i=5)$.

$\mathrm{O}_{\mathrm{M}}(5)$ is estimated at 75844 units, and $\mathrm{O}_{\mathrm{RT}}(5)$ is 72677 units. Since $\mathrm{O}_{\mathrm{M}}(5)$ is higher than $\mathrm{O}_{\mathrm{RT}}(5)$, there is throughput shortage; thus the throughput shortage of day $5,\left(\mathrm{~L}_{\mathrm{a}}(5)=3167\right.$ units) is carried forward to the $2^{\text {nd }}$ stage of production planning. For day $6, \mathrm{O}_{\mathrm{M}}(6)$ is estimated at 72967 units. The throughput shortage from day $5, \mathrm{~L}_{\mathrm{a}}(5)$ is added to the planned throughput of day $6, \mathrm{O}_{\mathrm{M}}(6) . \mathrm{O}_{\mathrm{B}}(6)$ is calculated as $\mathrm{O}_{\mathrm{M}}(6)+\mathrm{L}_{\mathrm{a}}(5)$ where it is equal to 76134 units. In the $2^{\text {nd }}$ stage, the mathematical programming assessed the adjusted cycle time within the boundary shown 
in Table 1 and estimated $\mathrm{O}_{C}(6)$ as 76134 units. Since $\mathrm{O}_{C}(6)$ is equal to $\mathrm{O}_{\mathrm{B}}(6)$, there is no predicted throughput shortage that is required to be carried forward to the next day $(\mathrm{i}=7)$.

For day $7, \mathrm{O}_{\mathrm{M}}(7)$ is estimated at 79716 units, and $\mathrm{O}_{\mathrm{RT}}(7)$ is 75200 . Since $\mathrm{O}_{\mathrm{M}}(7)$ is higher than $\mathrm{O}_{\mathrm{RT}}(7)$, there is throughput shortage; thus the throughput shortage of day $7,\left(\mathrm{~L}_{a}(7)=4516\right.$ units $)$ is carried forward to the $2^{\text {nd }}$ stage of production planning for day 8 . Since the case study is limited to seven days period, the analysis stops at this point.

\section{Case Study 3: Period 3}

Table 4 shows the production planning data obtained for the $3^{\text {rd }}$ period for 7 days.

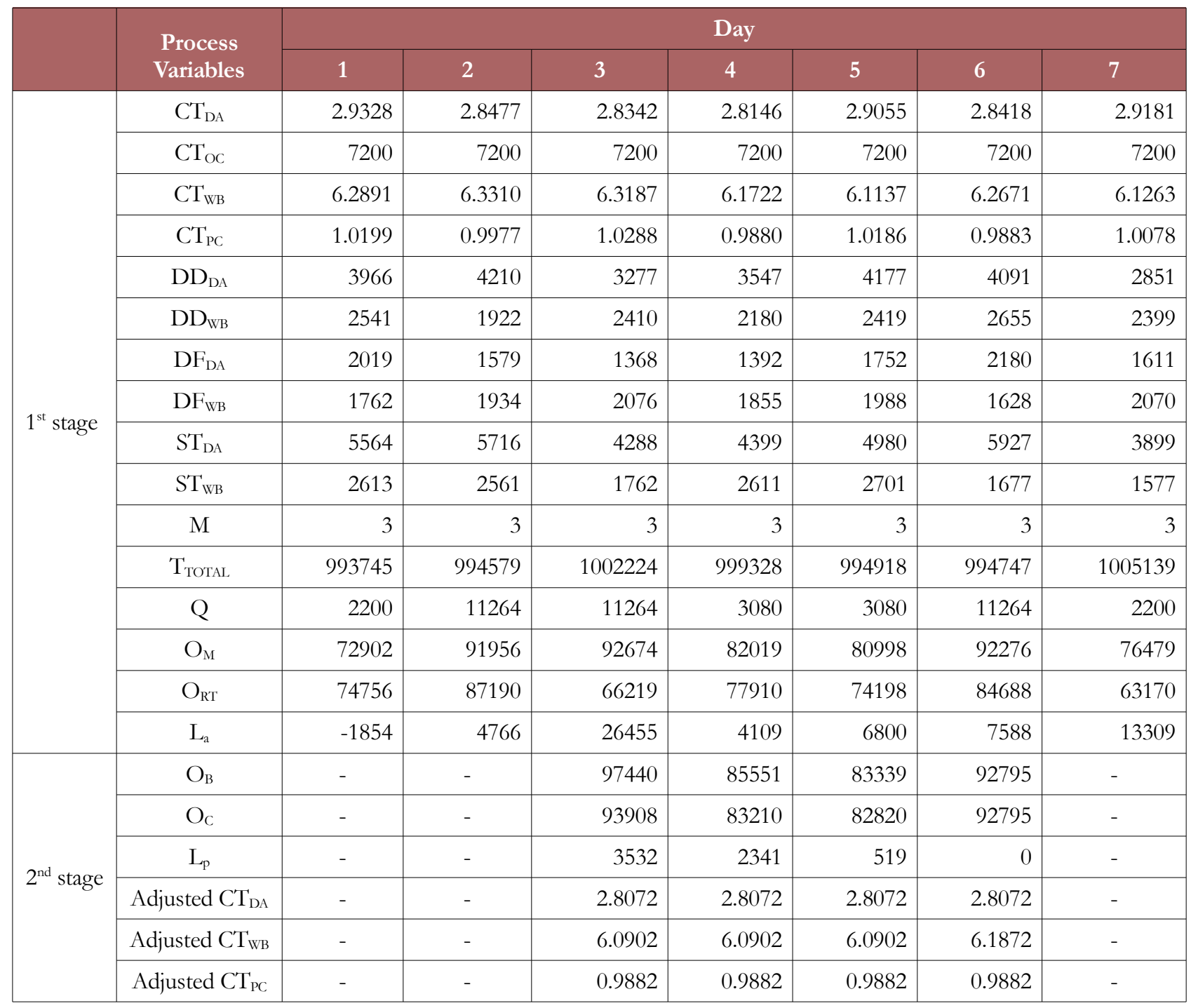

Table 4. $1^{\text {st }}$ Stage and $2^{\text {nd }}$ Stage of Production Planning for $3^{\text {rd }}$ Period

For day 1 in the $1^{\text {st }}$ stage of production planning, $\mathrm{O}_{\mathrm{M}}(1)$ is estimated at 72902 units. $\mathrm{O}_{\mathrm{RT}}(1)$ is 74756 units. Since $\mathrm{O}_{\mathrm{M}}(1)$ is lower than $\mathrm{O}_{\mathrm{RT}}(1)$, there is no throughput shortage to be carried to the $2^{\text {nd }}$ stage of production planning.

$\mathrm{O}_{\mathrm{M}}(2)$ is estimated at 91956 units, and $\mathrm{O}_{\mathrm{RT}}(2)$ is 87190 units. Since $\mathrm{O}_{\mathrm{M}}(2)$ is higher than $\mathrm{O}_{\mathrm{RT}}(2)$, there is throughput shortage; thus the throughput shortage of day 2, $\left(\mathrm{L}_{\mathrm{a}}(2)=4766\right.$ units) is carried forward to the $2^{\text {nd }}$ stage of production planning. For day $3, \mathrm{O}_{\mathrm{M}}(3)$ is estimated at 92674 units. The throughput shortage from day $2, \mathrm{~L}_{\mathrm{a}}(2)$ is added to the planned throughput of day $3, \mathrm{O}_{\mathrm{M}}(3) . \mathrm{O}_{\mathrm{B}}(3)$ is calculated as $\mathrm{O}_{\mathrm{M}}(3)+\mathrm{L}_{\mathrm{a}}(2)$ where it is equal to 97440 units. In the $2^{\text {nd }}$ stage, the mathematical programming assessed the adjusted cycle time within the boundary shown 
in Table 1 and estimated $\mathrm{O}_{\mathrm{C}}(3)$ as 93908 units. Since $\mathrm{O}_{\mathrm{C}}(3)$ is lower than $\mathrm{O}_{\mathrm{B}}(3)$, there is a predicted throughput shortage that is required to be carried forward to the next day $(i=4) . L_{p}(3)$ is 3532 units.

For day $4, \mathrm{O}_{\mathrm{M}}(4)$ is estimated at 82019 units. The predicted throughput shortage from day $3, \mathrm{~L}_{\mathrm{p}}(3)$ are added to the planned throughput of day $4, \mathrm{O}_{\mathrm{M}}(4) . \mathrm{O}_{\mathrm{B}}(4)$ is calculated as $\mathrm{O}_{\mathrm{M}}(4)+\mathrm{L}_{\mathrm{p}}(3)$ where it is equal to 85551 units. In the $2^{\text {nd }}$ stage, the mathematical programming assessed the adjusted cycle time within the boundary shown in Table 1 and estimated $\mathrm{O}_{\mathrm{C}}(4)$ as 83210 units. When $\mathrm{O}_{\mathrm{C}}(4)$ is lower than $\mathrm{O}_{\mathrm{B}}(4)$, there is a predicted throughput shortage that is required to be carried forward to the next day $(\mathrm{i}=5) . \mathrm{L}_{\mathrm{p}}(4)$ is 2341 units.

For day $5, \mathrm{O}_{\mathrm{M}}(5)$ is estimated at 80998 units. The predicted throughput shortage from day $4, \mathrm{~L}_{\mathrm{p}}(4)$ are added to the planned throughput of day $5, \mathrm{O}_{\mathrm{M}}(5) . \mathrm{O}_{\mathrm{B}}(5)$ is calculated as $\mathrm{O}_{\mathrm{M}}(5)+\mathrm{L}_{\mathrm{p}}(4)$ where it is equal to 83339 units. In the $2^{\text {nd }}$ stage, the mathematical programming assessed the adjusted cycle time within the boundary shown in Table 1 and estimated $\mathrm{O}_{\mathrm{C}}(5)$ as 82820 units. When $\mathrm{O}_{\mathrm{C}}(5)$ is lower than $\mathrm{O}_{\mathrm{B}}(5)$, there is a predicted throughput shortage that is required to be carried forward to the next day $(i=6)$. $L_{p}(5)$ is 519 units.

For day $6, \mathrm{O}_{\mathrm{M}}(6)$ is estimated at 92276 units. The predicted throughput shortage from day $5, \mathrm{~L}_{\mathrm{p}}(5)$ are added to the planned throughput of day $6, \mathrm{O}_{\mathrm{M}}(6) . \mathrm{O}_{\mathrm{B}}(6)$ is calculated as $\mathrm{O}_{\mathrm{M}}(6)+\mathrm{L}_{\mathrm{p}}(5)$ where it is equal to 92795 units. In the $2^{\text {nd }}$ stage, the mathematical programming assessed the adjusted cycle time within the boundary shown in Table 1 and estimated $\mathrm{O}_{C}(6)$ as 92795 units compare. When $\mathrm{O}_{C}(6)$ is equal to $\mathrm{O}_{\mathrm{B}}(6)$, there is no predicted throughput shortage that is required to be carried forward to the next day $(\mathrm{i}=7)$.

For day $7, \mathrm{O}_{\mathrm{M}}(7)$ is estimated at 76479 units, and $\mathrm{O}_{\mathrm{RT}}(7)$ is 63170 . Since $\mathrm{O}_{\mathrm{M}}(7)$ is higher than $\mathrm{O}_{\mathrm{RT}}(7)$, there is throughput shortage; thus the throughput shortage of day $7,\left(\mathrm{~L}_{a}(7)=13309\right.$ units $)$ is carried forward to the $2^{\text {nd }}$ stage of production planning for day 8 . Since the case study is limited to seven days period, the analysis stops at this point.

\section{The Implication of Throughput Shortage Recovery}

Table 5 shows the summary of losses data for each period.

\begin{tabular}{|l|r|r|r|}
\hline \multirow{2}{*}{\multicolumn{2}{|c|}{ Method }} & \multicolumn{3}{|c|}{ Throughput shortage accumulated by day 7 (units) } \\
\cline { 2 - 4 } & Case study 1 & Case study 2 & Case study 3 \\
\hline Conventional production planning model & 71862 & 64190 & 63027 \\
\hline Two-stage production planning model & 18951 & 4516 & 13309 \\
\hline
\end{tabular}

Table 5. Summary of losses data for Each Period

Table 2, Table 3, and Table 4 are essentially a simulation of the 2-stage of production planning to analyse throughput shortage occurrence. In the model, $\left(\mathrm{O}_{\mathrm{B}}-\mathrm{O}_{\mathrm{C}}\right)$ is analogous to $\left(\mathrm{O}_{\mathrm{M}^{-}} \mathrm{O}_{\mathrm{RT}}\right)$. $\left(\mathrm{O}_{\mathrm{B}}-\mathrm{O}_{\mathrm{C}}\right)$ reflects the condition of throughput shortage if the two-stage production planning model is adopted. Referring to Table 5 , the model can reduce the accumulated throughput shortage incurred over a week, based on a comparison of throughput shortage from conventional method (summation of $\mathrm{L}_{\mathrm{a}}$ over the 7 day period) and 2-stage of production planning model $\left(\mathrm{L}_{\mathrm{a}}\right.$ on day 7 if $L_{p}$ on day 6 is zero or negative, or $L_{p}$ on day 7 if $L_{p}$ on day 7 is positive).

It is shown that adopting the two-stage production planning model can recover the throughput shortage, but the production capacity always limits the system based on the boundary of process parameters. However, when the real-time throughput is lower than the planned throughput, it is subjected to the throughput shortage recovery mode, causing parameters adjustment to recover the throughput shortage and meet the demand for subsequent day simultaneously. If the adjusted parameters are outside the boundary of process parameters, there is flexibility in production capacity to recover the throughput shortage completely. However, this area has not been explored, as the boundary of process parameters ensures that the quality of the product is not compromised.

In production, the machine settings are not fixed during setup because the mechanical part adjustment complements the values of process parameters, resulting in a range of values for the machine settings (Pinedo, 
2005). Hence the cycle time can fluctuate. In addition, the presence of product variety is reflected by the fluctuation of the cycle time which is also induced by the range of machine settings due to setup and batch variation.

If the throughput shortage is not carried forward in the subsequent day of planning, it will create a backlog of unprocessed batches, thus interrupting the production flow and causing a delay in meeting the demand and due date. Also, when there is no adjustment on the process parameters, there is a possibility that there will be an additional generation of throughput shortage since the throughput shortage may not be recovered with the original setting of the process parameters. In practice, when the WIP build-up is too high, the loading of machines can be stopped to reduce the unprocessed backlog. The proposed model suppresses the need to stop machine loading when WIP build-up is too high, as WIP build-up is mitigated through the cycle time adjustment.

The planned capacity in a single process pushes the maximum throughput available to next process. The relationship between throughput and process parameters is typically established in a production planning model for a single process. As the manufacturing system becomes more complex, the structural configuration that relates to the number of processes become crucial for the model. The reason for integrating processes in planning instead of individual processes is it enables overview planning of the system that manages the products flow from the first process to the last process. It also ensures that the planned throughput is met at the end of the system. Integrating throughput shortage in the subsequent day of planning requires an active relationship between process parameters of integrated processes and planned throughput. When the number of processes increases, the number of process parameters also increases. Thus, it is a challenge to model a large number of processes and process parameters to perform estimation effectively.

Adjustment of process parameters plays an essential role in enhancing the competitiveness of an assembly semiconductor manufacturing system to meet demand and recover the throughput shortage. It improves the responsiveness to real-time throughput and throughput shortage. Chen (2013) proposed a planned cycle time reduction using a systematic procedure. However, the study still lacks a clear relationship between the process parameters and throughput shortage. Macher and Mowery (2003) and Chien, Hsu and Hsiao (2012) stated that adjustment of process parameters affects the productivity change by realigning the desired level of throughput in the production line. Although the process parameters are crucial to throughput performance, existing studies did not express the association between adjustment of process parameters with throughput and throughput shortage in the production planning model. The novelty of the proposed production planning model is the throughput and throughput shortage can be manipulated through adjustment of process parameters. Process parameters are adjusted within an allowable range of values at the 2nd stage, which is essential to maintain the product quality during the production run and recover the throughput shortage. This is because the adjusted parameters within these settings control and sustains the process variation to avoid product quality deviation during the production run (Kao, 2010; Michaloski, Zhao, Lee \& Rippey , 2013). Recurrence of product defect in such circumstances are caused by other factors such as tools wear and tear, quality of material, and other machine settings such as dispensing pressure, air pressure, or pattern recognition.

Indirectly, the cost of production improvement can be diverted to other activities since the process parameters can be adjusted with minimum cost. The significance of the framework is the establishment of a reference to develop the numerical relationship between process parameters with throughput and throughput shortage. Thus, it becomes feasible to adjust process parameters in multiple-process integration to plan for the future.

\section{Conclusion}

There is a possibility that the mathematical model of planned throughput may be higher than the actual throughput thus resulting in throughput shortage. A two-stage production planning model is proposed where mathematical programming plays an important role to meet the throughput shortage and planned throughput. The effectiveness of throughput prediction in the $2^{\text {nd }}$ stage of production planning uses an optimised set of process parameters within a defined range. The positive results from the three different periods indicate that the proposed two-stage production planning model is robust to manage the throughput planning in the real-time environment. 
There are few areas to extend this research. First, the inclusion of additional parameters such as material and resource availability can further improve the model representation to the manufacturing system. Second, existing parameters such as downtime and set up time can be included to enhance the model flexibility in meeting demand and restore the throughput shortage simultaneously. Third, the framework reference can be further extended to more processes to test the repeatability and reproducibility of the approach. A large number of validations can further generalise the model effectiveness in different settings.

\section{Declaration of Conflicting Interests}

The authors declared no potential conflicts of interest with respect to the research, authorship, and/or publication of this article.

\section{Funding}

The authors acknowledge the YUTP-FRG grant (0153AA-E36) provided by Yayasan UTP for funding the study that resulted in publishing this article.

\section{References}

Anantharaman, N., \& Nachiappan, R.M. (2006). Evaluation of Overall Line Effectiveness (OLE) in a Continuous Product Line Manufacturing System. Journal of Manufacturing Technology Management, 17(7), 987-1008. https://doi.org/10.1108/17410380610688278

Chan, S.W., Tasmin, R., Aziati, A.H.N., Rasi, R.Z., Ismail, F.B., \& Yaw, L.P. (2017). Factors Influencing the Effectiveness of Inventory Management in Manufacturing SMEs. IOP Conference Series: Materials Science and Engineering, 226(1). https://doi.org/10.1088/1757-899X/226/1/012024

Chen, T. (2013). A Systematic Cycle Time Reduction Procedure for Enhancing the Competitiveness and Sustainability of a Semiconductor Manufacturer. Sustainability (Switzerland), 5(11), 4637-4652. https://doi.org/10.3390/su5114637

Chien, C.F., Hsu, C.Y., \& Hsiao, C.W. (2012). Manufacturing Intelligence to Forecast and Reduce Semiconductor Cycle Time. Journal of Intelligent Manufacturing, 23(6), 2281-2294. https://doi.org/10.1007/s10845-011-0572-y

Enginarlar, E, Jingshan-Li, S.M.M., \& Zhang, R.Q. (2002). Buffer Capacity for Accommodating Downtime in Serial Production Lines. International Journal of Production Research, 40(3), 601-624. https://doi.org/10.1080/00207540110091703

Gandhi, A., \& Harchol-Balter, M. (2009). M/G/K with Exponential Setup. School of Computer Science. Carnegie Mellon University.

Gram, M. (2013). A Systematic Methodology to Reduce Losses in Production with the Balanced Scorecard Approach. Manufacturing Science and Technology, 2(1), 12-22. https://doi.org/10.13189/mst.2013.010103

Hassani, L., \& Hashemzadeh, G. (2015). The Impact of Overall Equipment Effectiveness on Production Losses in Moghan Cable \& Wire Manufacturing. International Journal for Quality Research, 9(4), 565-576. Available at: http://www.scopus.com/inward/record.url?eid=2-s2.0-84949643997\&partnerID=tZOtx3y1

Kao, S.C. (2010). Deciding Optimal Specification Limits and Process Adjustments under Quality Loss Function and Process Capability Indices. International Journal of Industrial Engineering: Theory Applications and Practice, 17(3), 212-222.

Khan. (2007). Industrial Engineering. New Age International.

Macher, J.T., \& Mowery, D.C. (2003). Managing" Learning by Doing: An Empirical Study in Semiconductor Manufacturing. Journal of Product Innovation Management, 20(5), 391-410. https:// doi.org/10.1111/1540-5885.00036

Michaloski, J.L., Zhao, Y.F., Lee, B.E., \& Rippey, W.G. (2013). Web-enabled, Real-time, Quality Assurance for Machining Production Systems. Procedia CIRP, 10, 332-339. https://doi.org/10.1016/j.procir.2013.08.051 
Miltenburg, J. (2000). The Effect of Breakdowns on U-shaped Production Lines. International Journal of Production Economics, 58(2), 183-189. https://doi.org/10.1080/002075400189455

Nemtajela, N., \& Mbohwa, C. (2017). Relationship between Inventory Management and Uncertain Demand for Fast Moving Consumer Goods Organisations. Procedia Manufacturing, 8(October), 699-706.

https://doi.org/10.1016/j.promfg.2017.02.090

Pinedo, M.L. (2005). Planning and Scheduling in Manufacturing and Services. Springer. United State of America. https://doi.org/10.1017/CBO9781107415324.004

Prajapati, M., \& Deshpande, V. (2015). Cycle Time Reduction using Lean Principles and Techniques: A Review. Journal, International Engineering, Industrial, 3(December).

Salameh, M.K., \& Ghattas, R.E. (2001). Optimal Just-In-Time Buffer Inventory for Regular Preventive Maintenance. International Journal of Production Economics, 74(1-3), 157-161. https://doi.org/10.1016/S09255273(01)00122-0

Sana, S.S., \& Chaudhuri, K.S. (2010). An EMQ Model in an Imperfect Production Process. International Journal of System Science, 41(6), 635-646. https://doi.org/10.1080/00207720903144495

Sana, S.S. (2012). Preventive Maintenance and Optimal Buffer Inventory for Products Sold with Warranty in an Imperfect Production System. International Journal of Production Research, 50(23), 6763-6774. https://doi.org/10.1080/00207543.2011.623838

Sharma, P., \& Jain, A. (2015). Stochastic Dynamic Job Shop Scheduling with Sequence-Dependent Setup Times: Simulation Experimentation. Journal of Engineering and Technology, 5(1), 19. https://doi.org/10.4103/0976-8580.149475

Siva, R., Patan, M.N.K., Kumar, M.L.P., Purusothaman, M., Pitchai, S.A., \& Jegathish, Y. (2017). Process Improvement by Cycle Time Reduction through Lean Methodology. IOP Conference Series: Materials Science and Engineering, 197(1). https://doi.org/10.1088/1757-899X/197/1/012064

Salvendry, G. (2007). Handbook of Industrial Engineering: Technology and Operations Management (3rd ed.). Wiley Online Library. https://doi.org/10.1002/9780470172339

Tekin, I., \& S1tk1, G. (2012). Determination of Costs Resulting from Manufacturing Losses: An Investigation in White Durables Industry. Proceedings of the 2012 International Conference on Industrial Engineering and Operations Management Istanbul, Turkey, 352-361.

Telsang, M. (2010). Industrial Engineering and Production Management. S. Chand and Company LTD, New Delhi.

Wuest, T., Weimer, D., Irgens, C., \& Thoben, K.D. (2016). Machine Learning in Manufacturing: Advantages, Challenges, and Applications. Production \& Manufacturing Research, 4(1), 23-45.

https://doi.org/10.1080/21693277.2016.1192517

Xu, X., Zhao, Y., Wu, M., Zhou, Z., Ma, Y., \& Liu, Y. (2016). Stochastic Customer Order Scheduling to Minimize Long-Run Expected Order Cycle Time. Annals of Operations Research, 7543(September), 1-24. https://doi.org/10.1007/s10479-016-2254-9

Zequeira, R.I, Prida, B., \& Valdes, J.E. (2004). Optimal Buffer Inventory and Preventive Maintenance for an Imperfect Production Process. International Journal of Production Research, 42(4), 959-974. https://doi.org/10.1080/00207540310001631610

Journal of Industrial Engineering and Management, 2019 (www.jiem.org)

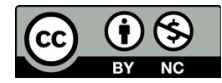

Article's contents are provided on an Attribution-Non Commercial 4.0 Creative commons International License. Readers are allowed to copy, distribute and communicate article's contents, provided the author's and Journal of Industrial Engineering and Management's names are included. It must not be used for commercial purposes. To see the complete license contents, please visit https://creativecommons.org/licenses/by-nc/4.0/. 